\title{
秋田県戸賀湾，秋田県金浦町地先，鳥取県泊村地先抢よび 島根県隠岐島島前湾におけるイワガキのグリコーゲン含量の季節変化
}

\author{
奥 村卓二, ${ }^{*}$ 三浦信 昭, $2 \mathrm{a}$ 勢 村 均, $3 \mathrm{~b}$ 岸本 好 博 $4 \mathrm{c}$ \\ (2004 年 8 月 30 日受付, 2005 年 1 月 4 日受理) \\ 1独水産総合研究センター養殖研究所, 2秋田県水産振興センター, \\ 3 島根県水産試験場鹿島浅海分場, ${ }^{4}$ 鳥取県水産試験場
}

Seasonal changes in glycogen contents of the Iwagaki oyster, Crassostrea nippona from the coast of Toga Bay, Konoura, Tomari, and Oki Islands in the Sea of Japan

\section{TAKUJI OKUMURA, ${ }^{1}$ NOBUAKI MIURA, ${ }^{2 \mathrm{a}}$ HITOSHI SEMURA ${ }^{3 b}$ AND YOSHIHIRO KISHIMOTOc}

\begin{abstract}
${ }^{1}$ National Research Institute of Aquaculture, Fisheries Research Agency, Nansei, Mie 516-0193, ${ }^{2}$ Akita Prefectural Institute for Fisheries and Fisheries Management, Funakawaminato, Oga, Akita 010-0531, ${ }^{3}$ Kashima Branch, Shimane Prefectural Fisheries Experimental Station, Kashima-cho, Shimane 690-0322, ${ }^{4}$ Tottori Prefectural Fisheries Experimental Station, Tomari-son, Tottori 689-0602, Japan
\end{abstract}

In general, oysters accumulate glycogen in the connective tissues for energy storage and utilize it during gonadal development. However, little is known about the glycogen accumulation in the Iwagaki oyster, Crassostrea nippona, an important species for the coastal fisheries in the Sea of Japan. In the present study, seasonal changes in the glycogen contents of the tissues of Iwagaki oysters from the coast of Toga Bay, Konoura, Tomari, and Oki Islands in the Sea of Japan were examined. Glycogen contents gradually decreased from May to September at the four sampling sites concomitantly with spawning. On the other hand, in the Pacific oyster Crassostrea gigas, it is known that glycogen contents are low even in July. This is probably due to the difference in spawning season between both species: August-September in the Iwagaki oyster and July-September in the Pacific oyster. Glycogen contents of cultured Iwagaki oysters were lower in July and September than those of wild ones. This was probably due to differences in the timing of the decrease in glycogen contents. Some unknown environmental factors might affect glycogen contents.

キーワード：グリコーゲン，イワガキ，季節変化

イワガキCrassostrea nippona は，広く養殖されてい るマガキCrassostrea gigas の近縁種であり, 潮間帯に生 息するマガキよりもやや深い水深帯に生息する。1)イワ ガキは，マガキに比べて産卵期が 8～9 月と遅く, 1,2)さ らに徐々に産卵・放精する特徵を持つ。そのため, 夏で も成熟・産卵によりやせることがなく, 夏場でもおいし
いカキとして日本海沿岸を中心に地域特産的に流通して いる。流通しているイワガキの多くは天然貝であるが, 島根県隠岐島のように垂下養殖したイワガキを特産とし ているところもある。3

カキ類は一般にグリコーゲンをエネルギー源として体

内に多量に蓄えている。4-6) その量は乾燥重量の $20 \sim 40$

* Tel : 81-599-66-1830. Fax : 81-599-66-1962. Email : takuji@affrc.go.jp

a 現所属：秋田県農林水産部水産漁港課 (Fisheries and Fishing Ports Division, Akita Prefectural Government, Sanno, Akita 010-8570, Japan)

b 現所属：島根県農林水産総務課 (Department of Agriculture, Forestry, and Fisheries, Shimane Prefectural Government, Tonomachi, Matsue 690-8501, Japan)

c 現所属 : 鳥取県農林水産部市場開拓課 (Market Cultivation Division, Tottori Prefectural Government, Higashimachi, Tottori 6808570, Japan) 
\%になるが，成熟期から産卵期にかけて生殖腺発達に 消費されて急激に減少する。-6) また，グリコーゲンは 食味の一要素であることが知られており, カキがおいし いとされる時期とグリコーゲン含量が高い時期とが一致 する。

カキ類の体内グリコーゲン含量は栄養状態と食味の指 標となるが，イワガキに抢いては，青森県陸奥湾のイワ ガキの報告4)があるものの地域差や生息形態とグリコー ゲン含量との関係についてはよくわかっていない。本研 究では, 秋田県戸賀湾, 秋田県金浦町地先, 鳥取県泊村 地先および島根県隠岐島島前湾からイワガキを採集して グリコーゲン含量を調べ, その季節変化, 地域差および 生息形態による差を明らかにした。

\section{試料および方法}

サンプリング イワガキ試料を，秋田県戸賀湾（以 下, 戸賀, TOGA), 秋田県金浦町地先 (以下, 金浦, KONOURA), 鳥取県泊村地先 (以下, 泊, TOMARI) および島根県隠岐島島前湾（以下, 隠岐, OKI）から採 集した（Fig. 1, Table 1)。天然イワガキは潜水により 採集し, 養殖イワガキは垂下養殖しているものを引き上 げて採集した。採集した個体（各サンプリング毎に 10 ２0 個体）はすみやかに冷凍し， $-30^{\circ} \mathrm{C}$ で分析まで保 存した。

分析 グリコーゲンの分析は既報7,8)にしたがって行 った。採集し凍結したイワガキから各採集地点の各採集 月毎に無作為に 8 個体ずつ選び, 半解凍状態にしてか ら軟体部をとりだし, 重量測定後, 10 倍量の純水中で ホモジナイザー（日立工機：HG-30）を用いてホモジ

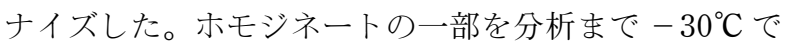
凍結保存した。ホモジネートの一部 $(0.5 \mathrm{~mL})$ を水酸 化カリウム溶液中で分解・抽出した後, エタノールを添 加して抽出されたグリコーゲンを沈殿させた。得たグリ コーゲンを硫酸溶液中で加水分解させ, 生じたグルコー 久を酵素法に基づく測定キット（和光純薬：GlucoseCII-test-Wako）で測定した。本キットでは，まずグル コースオキシダーゼによりグルコースを分解して過酸化 水素を生成させ，過酸化水素とペルオキダーゼの作用で 生じる赤色色素の量を吸光度から求めることで試料中の グルコース量を定量する。加水分解後の試料液を中和 し，その一部 $(0.1 \mathrm{~mL})$ に測定キットの反応液 $(3 \mathrm{~mL})$ を加えて室温で 15 分間反応させ, 吸光度 $(505 \mathrm{~nm})$ を 測定した。標準品としてカキグリコーゲン（Sigma）を 用いた。また，ホモジネートの一部 $(4 \mathrm{~mL})$ を凍結乾 燥して, ホモジネートの乾燥重量を求めた。

統計検定 測定結果は, 組織乾燥重量あたりのグリ コーゲン含量として平均と標準偏差で表した。統計検定 にはノンパラメトリック法を用いた。2 群間の比較は

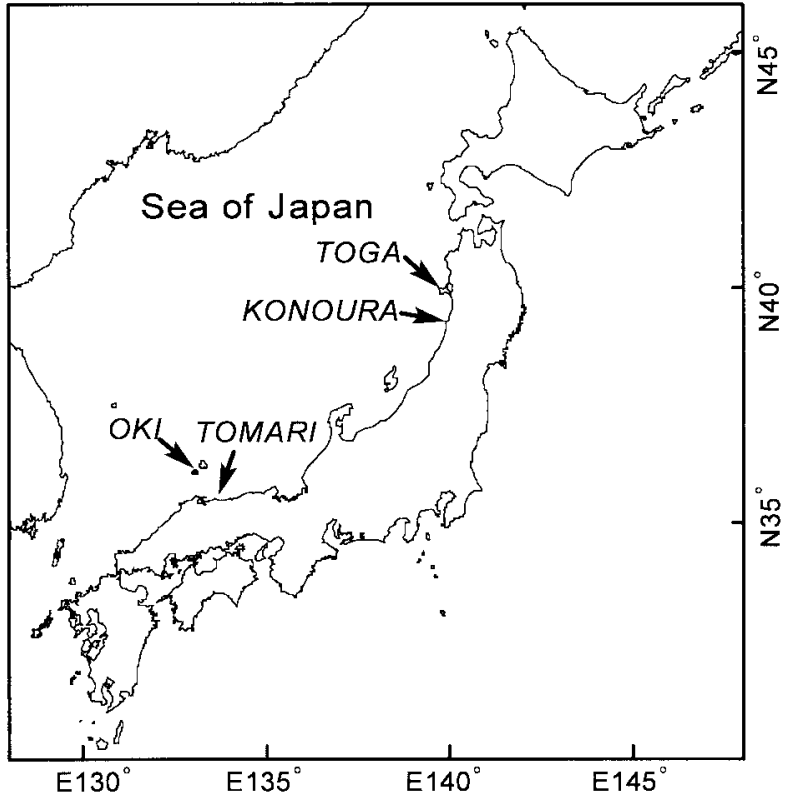

Fig. 1 Location of the four sampling sites in the Sea of Japan.

Mann-Whitney’s U-test で検定した。多重比較をする際 は, Kruskal-Wallis test で全体の有意差を検定した後に Steel-Dwass test で各群間の検定を行った。危険率が $p$ $<0.05$ の場合に有意差があるとした。

\section{結果}

地域間の比較 グリコーゲン含量の地域間の差を明ら かにするために，成熟期から産卵期にあたる 5, 7, 9 月 (1998 年。ただし隠岐のみ 1999 年で， 5 月のサンプリ ングは 6 月 2 日に行った）の試料について戸賀, 金浦, 泊, 隠岐で比較した (Fig. 2)。用いた試料は, 戸賀, 金浦, 泊は天然イワガキであり, 隠岐は養殖イワガキで あった。 4 地域とも， 5 月から 9 月にかけてグリコーゲ ン含量が有意に減少した $(p<0.05)$ 。地域間で比較す ると, 5,7 月のグリコーゲン含量は隠岐で有意に低く $(p<0.05), 9$ 月は泊で有意に高かった $(p<0.05)$ 。

隠岐における周年変化 地域を問わずグリコーゲン含 量が生殖周期と関連することが示唆されたため, グリ コーゲン含量の季節変化をより明らかにするために, 日 本海沿岸特有の波浪が強い冬季でもサンプリングが容易 な隠岐の養殖イワガキを用いてグリコーゲン含量の周年 変化を調べた (Fig. 3)。グリコーゲン含量は, 産卵終 了後いわゆる「水ガキ」状態になる 10 月（1998 年）に 最も低かったが, 回復期の 11 月（1998 年）には個体差 が大きくなった。さらに，1～7月（1999 年）に高くな り, 産卵期末期の 9 月（1999 年）には低くなった。以 上のように, グリコーゲン含量は生殖周期と関連した季 
Table 1 Sampling profiles

\begin{tabular}{|c|c|c|c|c|c|c|}
\hline Sites & Date & Source & $\begin{array}{l}\text { Sampling } \\
\text { depth (m) }\end{array}$ & $\begin{array}{c}\text { Surface } \\
\text { temperature } \\
\left({ }^{\circ} \mathrm{C}\right)\end{array}$ & $\begin{array}{l}\text { Whole body } \\
\text { weight }(\mathrm{g})^{* 4}\end{array}$ & $\begin{array}{c}\text { Soft body } \\
\text { weight }(\mathrm{g}) * 4\end{array}$ \\
\hline \multirow[t]{15}{*}{ Toga } & 26 May, 1998 & wild & $4-5$ & 16.0 & $299 \pm 41$ & $57.5 \pm 11.7$ \\
\hline & $23 \mathrm{Jul}, 1998$ & wild & $4-5$ & 24.3 & $300 \pm 50$ & $57.5 \pm 12.8$ \\
\hline & 21 Sep, 1998 & wild & $4-5$ & 24.6 & $247 \pm 55$ & $25.6 \pm 11.0$ \\
\hline & 10 May, 2000 & wild & $4-5$ & 14.5 & $263 \pm 63$ & $51.8 \pm 16.4$ \\
\hline & 14 Jul, 2000 & wild & $4-5$ & 21.6 & $269 \pm 57$ & $56.0 \pm 11.2$ \\
\hline & 12 Sep, 2000 & wild & $4-6$ & 25.2 & $286 \pm 43$ & $50.7 \pm 10.0$ \\
\hline & 20 Nov, 2000 & wild & $6-7$ & 15.3 & $265 \pm 62$ & $41.2 \pm 5.8$ \\
\hline & 9 Jan, 2001 & wild & $5-6$ & 9.9 & $307 \pm 45$ & $50.3 \pm 10.4$ \\
\hline & 22 Mar, 2001 & wild & $5-6$ & 9.7 & $260 \pm 99$ & $47.8 \pm 17.0$ \\
\hline & 10 May, 2000 & cultured & $2-3$ & —*2 & $226 \pm 20$ & $45.7 \pm 11.7$ \\
\hline & 14 Jul, 2000 & cultured & $2-3$ & —*2 & $207 \pm 29$ & $41.9 \pm 4.8$ \\
\hline & 12 Sep, 2000 & cultured & $2-3$ & —*2 & $207 \pm 26$ & $42.7 \pm 7.3$ \\
\hline & 20 Nov, 2000 & cultured & $3-4$ & —*2 & $236 \pm 27$ & $40.5 \pm 6.6$ \\
\hline & 9 Jan, 2001 & cultured & $3-4$ & —*2 & $199 \pm 21$ & $37.9 \pm 6.1$ \\
\hline & 22 Mar, 2001 & cultured & $2-3$ & —*2 & $263 \pm 62$ & $51.8 \pm 10.7$ \\
\hline \multirow[t]{3}{*}{ Konoura } & 21 May, 1998 & wild & $3-5$ & 19.8 & $291 \pm 49$ & $49.8 \pm 4.9$ \\
\hline & $21 \mathrm{Jul}, 1998$ & wild & $3-5$ & 24.4 & $258 \pm 29$ & $49.0 \pm 10.6$ \\
\hline & 14 Sep, 1998 & wild & $3-5$ & 24.4 & $228 \pm 48$ & $25.9 \pm 15.1$ \\
\hline \multirow[t]{3}{*}{ Tomari } & 12 May, 1998 & wild & 5 & $17.0^{* 3}$ & $319 \pm 56$ & $56.4 \pm 8.3$ \\
\hline & 15 Jul, 1998 & wild & 5 & $24.6^{* 3}$ & $339 \pm 59$ & $55.1 \pm 7.5$ \\
\hline & $21 \mathrm{Sep}, 1998$ & wild & 5 & $26.2^{* 3}$ & $352 \pm 77$ & $42.9 \pm 6.5$ \\
\hline \multirow[t]{7}{*}{ Oki } & 5 Oct, 1998 & cultured & 10 & 24.3 & $110 \pm 21$ & $19.4 \pm 5.1$ \\
\hline & 3 Nov, 1998 & cultured & 10 & —*2 & $148 \pm 38$ & $27.1 \pm 7.1$ \\
\hline & 19 Jan, 1999 & cultured & 10 & —*2 & $164 \pm 30$ & $32.6 \pm 7.4$ \\
\hline & 15 Mar, 1998 & cultured & 10 & 12.9 & $282 \pm 36$ & $56.2 \pm 9.8$ \\
\hline & 2 Jun, $1998^{* 1}$ & cultured & 10 & 20.7 & $268 \pm 54$ & $68.5 \pm 14.6$ \\
\hline & 16 Jul, 1998 & cultured & 10 & —*2 & $284 \pm 26$ & $65.6 \pm 12.3$ \\
\hline & 8 Sep, 1998 & cultured & 10 & —*2 & $241 \pm 29$ & $45.6 \pm 13.0$ \\
\hline
\end{tabular}

*1: This sampling was done for the sample of May 1999.

$* 2$ : Temperature was not measured.

*3 : Temperature at $5 \mathrm{~m}$ depth

${ }^{* 4}$ : Mean and standard deviation

節変化を示した。

生息形態との関係 隠岐の養殖イワガキのグリコーゲ ン含量が低かったため（Fig. 2), 垂下養殖されている 養殖イワガキと岩礁等に固着している天然イワガキとの 生息形態の違いがグリコーゲン含量に影響する可能性を 確認するために，戸賀で養殖イワガキと天然イワガキと を周年採集してグリコーゲン含量を比較した (Fig. 4)。 天然イワガキのグリコーゲン含量は, 5 月に高く, 産卵 期末期の 9 月から回復期の 3 月にかけて低かった。養 殖イワガキのグリコーゲン含量は, 3 月から 7 月に高 く, 産卵期末期と終了後の 9 月から 11 月に低かった。 各月ごとに天然イワガキと養殖イワガキのグリコーゲン 含量を比較すると, 7 月と 9 月で養殖イワガキの方が低 かった $(p<0.05)$ 。

\section{考察}

本研究では，イワガキのグリコーゲン含量を測定し， その季節変化, 地域差や生息形態との関係を調べた。そ の結果, イワガキのグリコーゲン含量が生殖周期と関連 して季節変化すること, 養殖イワガキと天然イワガキと では季節変動の様子に差が見られることが明らかになっ た。

マガキでは, 消化器官と生殖腺の間にある結合組織に グリコーゲンが蓄積され, 生殖腺の発達時にエネルギー 源として利用されてグリコーゲンの蓄積が急激に減少す

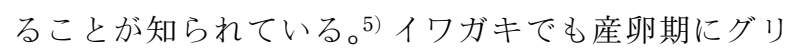
コーゲン含量が減少したのは, 同様に生殖腺の発達にグ リコーゲンが利用されたためと考えられる。マガキの場 


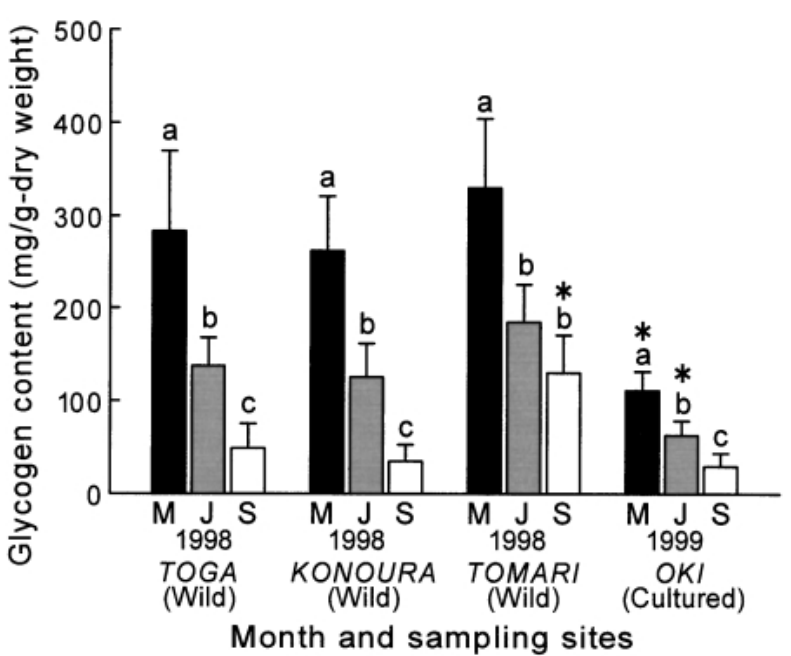

Fig. 2 Glycogen contents of wild or cultured Iwagaki oysters from the sampling sites. M, May; J, July; S, September. Bars indicate mean and SD of eight animals. Bars without common letters indicate significant differences $(p<0.05)$ between months at each sampling site, and asterisks indicate significant differences $(p<0.05)$ between the four sampling sites in each month. The samples of May in Oki Islands were taken on 2 June, 1999.

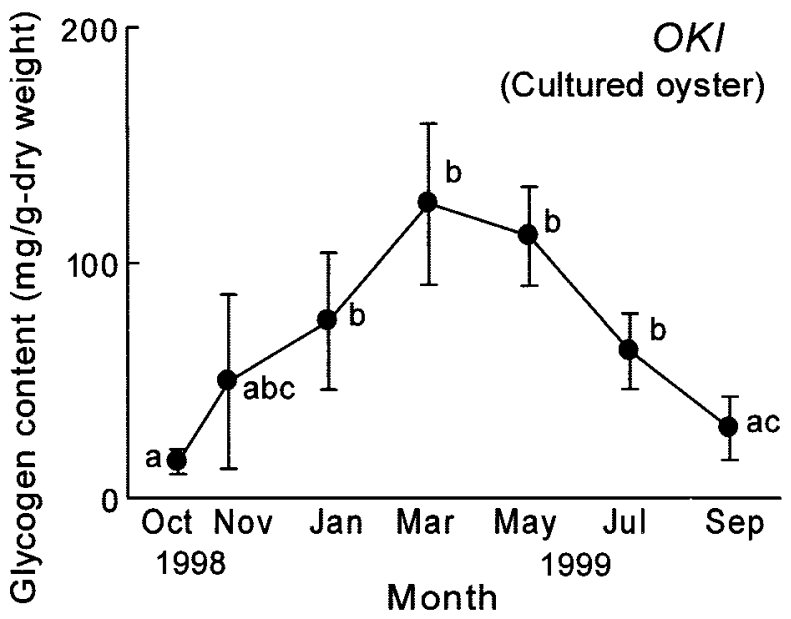

Fig. 3 Seasonal change in glycogen contents of cultured Iwagaki oysters from Oki Islands. Points and bars indicate mean and SD of eight animals. Points and bars without common letters indicate significant differences $(p<0.05)$. Data for May, July, and September, 1999 are the same as those in Fig. 2.

合，グリコーゲン含量の減少は 6 月から 8 月にかけて おきる。 キでは 7 月でもグリコーゲン含量は高く, 9 月から 10 月に低くなった。この違いは畑井の報告4)ともほぼ一致 する。こうしたグリコーゲン含量の季節変化の差は, イ ワガキではマガキよりも産卵期が遅くさらに産卵・放精

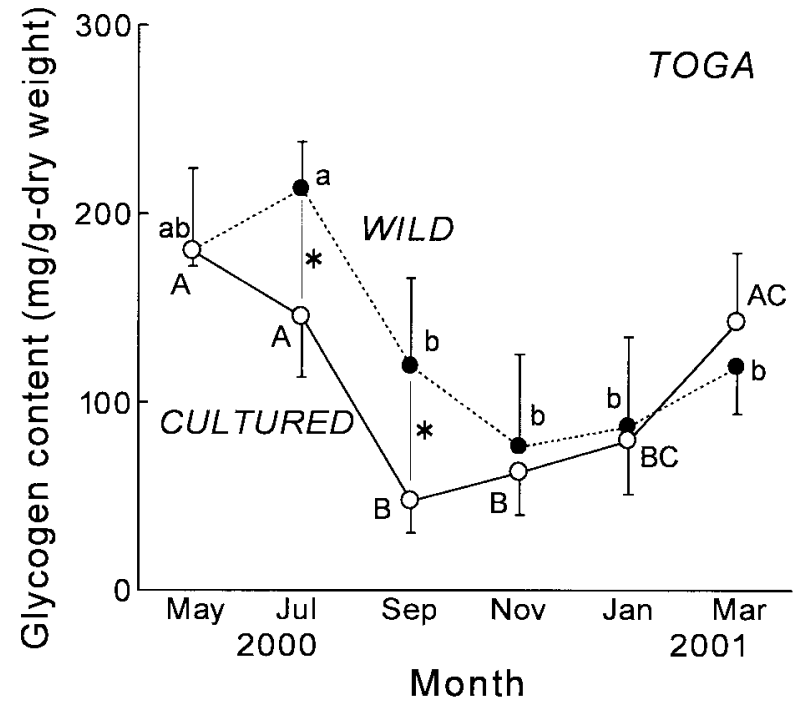

Fig. 4 Seasonal changes in glycogen contents of wild and cultured Iwagaki oysters from Toga Bay. Points and bars indicate mean and SD of eight animals. Points and bars without common letters (lowercase for wild oyster and uppercase for cultured oyster) indicate significant differences $(p<0.05)$ between months, and asterisks indicate significant differences $(p<0.05)$ between wild and cultured oysters.

を徐々に行うといった産卵生態の違いを反映していると 考えられる。生殖腺発達が抑制される三倍体マガキでは 産卵期にともなうグリコーゲンの減少も抑制されるとい う報告10)があり，産卵生態の差がグリコーゲン含量の 変化に影響することを示唆する。また, グリコーゲン蓄 積の最大值がマガキ（乾燥重量で約 40\%) 4-6) よりもイ ワガキ（乾燥重量で約 20～35\%）の方が低かったが, 種による差とともに, イワガキの生息域がより外洋性で あるため植物プランクトンなどの餌料が少ないことも影 響したと考えられる。

秋田県戸賀湾, 秋田県金浦町地先, 鳥取県泊村地先打 よび島根県隠岐島島前湾の 4 地域でイワガキのグリ コーゲン含量を比較した結果, 4 地域とも生殖周期にと もなう変化が見られたが， 5,7 月は隠岐で低く，9月は 泊で高い地域差が見られた。隠岐で低かったのは, 他の 地域の試料が天然イワガキであるのに対して養殖イワガ キであることと, 生息水深が $10 \mathrm{~m}$ と他の地域（水深 2 〜 m) よりも深いことが関与していると考えられる。 泊で 9 月に高かったのは, もっとも南の地点で水温が 高いことが影響して他の地点と産卵期がずれ，産卵期の 途中であったか，またはすでに産卵期を終了して回復期 に入っていた可能性が考えられる。イワガキの分布域は 広く, 南北に離れた地域間では産卵期などが異なってグ リコーゲン含量の季節変化に差が生じるのだろう。マガ キでは水温が産卵期に影響することが報告されてお 
り,11）実際に有明海と宮城のように南北に離れた地点で は産卵期がずれることが知られている。

戸賀の試料で天然イワガキと養殖イワガキとのグリ コーゲン含量を比較したところ, 7, 9 月に養殖イワガキ の方が天然イワガキよりも低い結果が得られた。養殖イ ワガキのグリコーゲン含量が最も高い 5 月では養殖と 天然の間に差がないことから，両者の間でグリコーゲン の最大蓄積量に大きな差がないと見られ，グリコーゲン 含量が減少する時期が養殖イワガキの方が早いために 7, 9 月に差が生じたと考えられる。

こうした差が生じた原因としては, 天然イワガキと養 殖イワガキの生息環境（波浪, 水温) や生理条件 (生殖, 成長）が以下のように異なっていたことが影響したと考 えられる。天然イワガキと養殖イワガキを採集した地点 は約 $800 \mathrm{~m}$ しか離机ていないが，天然イワガキは波浪 を受けやすい岩礁域に生息するのに対して養殖イワガキ は波浪をさけて湾奥で垂下養殖されるため, 波浪の影響 が異なる。また水温も, 養殖イワガキの採集地点の方が より湾奥で浅いため, わずかながら高かった可能性があ る。産卵期について秋田県椿地先で調べられた結果によ ると, 環境要因は不明だが, 天然イワガキよりも養殖イ ワガキの方が放卵・放精期が遅くまで続くことが報告さ れている。 ${ }^{12)}$ さらに，垂下養殖したイワガキでは天然よ りも成長が速いことが報告されており，3,13）養殖イワガ キではグリコーゲンの蓄積よりも成長にエネルギーが使 われた可能性がある。天然と養殖とでは成長差があるた め, 実験に用いたイワガキは同じ体重でも, 天然イワガ キの年齢が 5 歳以上と推定されるのに対して養殖イワ ガキは $2 \sim 3$ 歳であった。天然と養殖イワガキの間に見 られたグリコーゲン含量の違いは，こうした生息環境条 件や生理条件が複合的に関係して生じたと考えられる。

これまでにマガキなど貝類のグリコーゲン含量に影響 を与える環境要因として, 饂料環境, ${ }^{14,15)}$ 水交換環 境, ${ }^{16)}$ 水温環境, ${ }^{17)}$ や波浪環境 ${ }^{18)}$ が知られている。これ らの環境要因の中で, グリコーゲンが余剩栄養として蓄 積されることから䬶料環境がグリコーゲンの蓄積に重要 であり, 成熟のエネルギー源としてグリコーゲンが消費 されることから，グリコーゲンの減少には成熟に影響す る水温環境と餌料環境が重要と考えられる。イワガキで も同様だと思われるが，イワガキの慨料環境や成熟生態 には不明な点が多く, 因果関係をはっきりさせるために はさらに研究が必要である。

戸賀の天然イワガキのグリコーゲン含量が，1998 年 では 5 月から 7 月に有意に減少したのに, 2000 年では 5 月と 7 月の間に差がなかった。原因として生息環境条 件の違いが考えられるが， 3 月から 9 月の間の戸賀の海 面水温は 1998 年と 2000 年の間に明瞭な差が見られな かった。水温以外の環境条件が影響したと考えられるが
特定はできない。イワガキのグリコーゲン含量は, 全体 の傾向として 5 月あたりをピークに 3 月から 7 月に高 く 9 月から 10 月に低くなる季節変化を示すが, 季節変 化の詳細については年により変動すると考えられる。

本研究では, イワガキのグリコーゲン含量の季節変化 抢よび，地域差や生息形態との関係を明らかにした。マ ガキと異なって夏でもグリコーゲン含量が比較的高かっ たことは, イワガキ特有の産卵生態と関連すると考えら れ, 夏でも掞いしいとされるイワガキの評判と一致す る。また, 地域間や養殖と天然イワガキの間で, グリ コーゲン含量に差が見られたのは, 水温などの生息環境 や生殖・成長などの生理条件が影響を与えた結果と考え られた。グリコーゲン蓄積についてはマガキでよく研究 されているが, 主として養殖マガキが研究の対象になっ て抢り, 天然のカキ類に関する知見は少なかった。力キ 類は種類により生態が異なることが知られており, 本研 究で天然イワガキのグリコーゲン含量の季節変動を明ら かにしたことは, マガキを含めたカキ類のグリコーゲン 蓄積と生態との関連を理解する上で役立つと考えられ る。

\section{謝辞}

本研究の遂行にあたり多大な助言をいただいた, 水産 総合研究センター日本海区水産研究所海区水産業研究部 海区産業研究室の林 育夫室長に厚く打礼申し上げま す。

\section{文献}

1）森 勝義. イワガキ. 日本の希少な野生水生生物に関す る基礎資料 1, 水産庁, 東京. 1994; 62-68.

2）道家章生, 宗清正廣, 辻 秀二, 井谷匡志. 若狭湾西部 海域に抢けるイワガキの生殖周期. 栽培技研 1998; 26 : 91-98.

3) 勢村 均, 石田健次, 中上 光, 林 育夫. 島根県隠岐 島島前湾に抢ける垂下養殖イワガキの成長. Venus 2001; 60: 93-102.

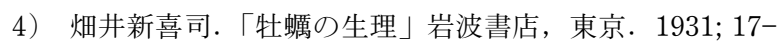
20.

5）今井丈夫, 沼地健一, 森 勝義, 菅原義男. 力キの生物 学的研究. 「浅海完全養殖」(今井丈夫, 猪野峻, 黒木 宗尚, 藤永元作, 山本護太郎編）恒星社厚生閣, 東京. 1971: 81-148.

6）大泉重一, 伊藤 進, 小金沢昭光, 酒井誠一, 佐藤隆 平, 菅野 尚. 力キ養殖の技術. 「浅海完全養殖」(今井 丈夫, 猪野 峻, 黒木宗尚, 藤永元作, 山本護太郎編） 恒星社厚生閣, 東京. 1971: 149-185.

7) Da Silva RSM, Zancan DM. Seasonal variation of the carbohydrate and lipid metabolism in a land pulmonate gastropod, Megalobulimus oblongus. Comp. Biochem. Physiol. 1994; 108A: 337-341.

8) Okumura T, Nagasawa T, Hayashi I, Sato Y. Effects of starvation on RNA: DNA ratio, glycogen content, and C: $\mathrm{N}$ ratio in columellar muscle of the Japanese turban shell Turbo (Batillus) cornutus (Gastropoda). Fish. Sci. 2002; 
68: 306-312.

9) Li Q, Osada M, Mori K. Seasonal biochemical variations in Pacific oyster gonadal tissue during sexual maturation. Fish. Sci. 2000; 66: 502-508.

10) Allen Jr SK, Downing SL. Performance of triploid Pacific oysters, Crassostrea gigas (Thunberg), I. survival, growth, glycogen content, and sexual maturation in yearlings. J. Exp. Mar. Biol. Ecol. 1986: 102: 197-208.

11) Chávez-Villalba J, Pommier J, Andriamiseza J, Pouvreau S, Barret J, Cochard JC, Le Pennec M. Broodstock conditioning of the oyster Crassostrea gigas: origin and temperature effect. Aquaculture 2002; 214: 115-130.

12）三浦信昭, 佐藤善雄. イワガキの天然と養殖における産 卵生態の相違について. 平成 11 年度日本海ブロック増 養殖研究推進連絡会議講演要旨集, 日本海区水産研究 所, 新潟. $2000 ; 28-30$.

13） 三浦信昭. 秋田県男鹿半島脇本沿岸におけるイワガキの 年齢と成長. 平成 15 年度日本海ブロック増養殖研究推 進連絡会議講演要旨集, 日本海区水産研究所, 新潟. $2004 ; 2-3$.

14) Whyte JNC, Englar JR, Carswell BL. Biochemical composition and energy reserves in Crassostrea gigas exposed to different levels of nutrition. Aquaculture 1990; 90: 157172.

15) Kang CK, Park MS, Lee PY, Choi WJ, Lee WC. Seasonal variations in condition, reproductive activity, and biochemical composition of the pacific oyster, Crassostrea gigas (Thunberg), in suspended culture in two coastal bays of Korea. J Shellish Res. 2000; 19: 771-778.

16) Almeida MJ, Machado J, Coimbra J. Growth and biochemical composition of Crassostrea gigas (Thunberg) at three fishfarm earthern ponds. J Shellfish Res. 1997; 16: 455-462.

17) Mann R. Some biochemical and physiological aspects of growth and gametogenesis in Crassostrea gigas and Ostrea edulis growth at sustained elevated temperatures. J. Mar. Biol. Assoc. U.K. 1979; 59: 95-110.

18) Wells RMG, McShane PE, Ling N, Wong RJ, Lee TOC, Baldwin J. Effect of wave action on muscle composition, metabolites and growth indices in the New Zealand abalone, paua (Haliotis iris), with implications for harvesting and aquaculture. Comp. Biochem. Physiol. 1998; 119B: 129 -136 . 